\title{
KONTRIBUSI PENERIMAAN RETRIBUSI PARKIR TERHADAP PENDAPATAN ASLI DAERAH KABUPATEN JEMBER
}

\author{
Kahar Haerah \\ Prodi Ilmu Pemerintahan FISIP Universitas Muhammadiyah Jember \\ kaharhaerah66@gmail.com
}

Received: 27 Januari 2018, Revised: 16 Februari 2018, Accepted: 25 Februari 2018

\begin{abstract}
Abstrak
Tujuan penelitian ini adalah: 1) untuk memberikan gambaran tentang kontribusi penerimaan retribusi parkir terhadap Pendapatan Asli Daerah Jember; 2) untuk memberikan gambaran tentang manajemen pengelolaan retribusi parkir yang baik, sehingga mampu meningkatkan Pendapatan Asli Daerah dari sektor retrbusi parkir. Jenis penelitian ini termasuk penelitian deskriptif kuantitatif yang sumber datanya diperoleh dari data primer dan data sekunder. Pengumpulan data diperoleh melalui teknik wawancara, observasi non partisipan dan studi dokumentasi. Setelah semua data terkumpul kemudian dianalisis dengan teknik analisis data deskriptif kuantitatif. Urgensi atau keutamaan penelitian ini antara lain: 1) memberikan sumbangsih teori terhadap pengembangan ilmu pengetahuan khususnya bidang ilmu pemerintahan; 2) Memberikan sumbangan pemikiran terhadap instansi terkait di Kabupaten Jember tentang pentingnya manajemen pengelolaan retribusi parkir sehingga bisa meningkatkan pendapatan asli daerah dari sektor retribusi parkir; 3) penelitian ini diharapkan juga bisa menjadi bahan referensi bagi peneliti selanjutnya yang ingi meneliti topik yang sama.
\end{abstract}

Kata Kunci: Retribusi Parkir, Pendapatan Asli Daerah

\begin{abstract}
The purpose of this study are: 1) to provide an overview of the contribution of the receipt of parking fees to the original revenue of Jember; 2) to provide an illustration of the management of a good parking levy management, so as to increase the original revenue from the parking retrbusi sector. Source data obtained from primary data and secondary data. In this descriptive quantitative research, data collection was obtained through interview technique, non participant observation and documentation study. After all the data collected then analyzed with quantitative descriptive data analysis techniques. Urgency or primacy of this research include: 1) contributing theory to the development of science, especially in the field of governmental sciences; 2) To give thought contribution to related institution in Jember Regency about the importance of parking levy management management so that it can increase the original revenue of the area from the parking charges; 3$)$ this study is also expected to be a reference material for further researchers who want to research the same topic. Keywords: Parking Levy, Local Revenue
\end{abstract}




\section{BAB 1. PENDAHULUAN}

\subsection{Latar Belakang}

Berdasarkan Tap MPR RI Nomor : X/MPR/1998 tentang pokok-pokok Reformasi Pembangunan Dalam Rangka Penyelamatan dan Normalisasi Kehidupan Nasional Sebagai Haluan Negara dan Tap MPR RI Nomor: XV/MPR/1998 tentang penyelenggaraan Otonomi Daerah, Pengaturan, Pembagian, dan Pemanfaatan Sumberdaya Nasional Yang Berkeadilan serta Perimbangan Keuangan Pusat dan Daerah dalam Kerangka Negara Kesatuan Repblik Indonesia, maka tuntutan masyarakat daerah dalam rangka pelaksanaan otonomi yang lebih nyata diwujudkan melalui perubahan kewenangan perencanan pengelolaan dana pembangunan melalui pengalihan wewenang dalam pengelolaan dana pembangunan di daerah serta melalui pembagian keuangan pusat dan daerah dalam rangka penguatan sumber dana pembangunan di daerah itu sendiri.

Berdasarkan arah pembangunan di era reformasi ini, maka inti dari pelaksanaan otonomi daerah adalah sistem hubungan keuangan pusat dan daerah. Untuk mendapatkan sistem hubungan keuangan pusat dan daerah yang baik dan sesuai dengan yang diinginkan, yang pertama-tama perlu dilihat adalah tujuan ekonomi dan politik dengan adanya sistem tersebut. Tujuan ekonomi dari sistem keuangan Pusat Daerah adalah terciptanya stabilitasi makro-ekonomi dan tercapainya efisiensi kinerja perekonomian karena dengan otonomi diharapkan pembangunan di daerah akan lebih cepat dan ekonomis karena dilakukan oleh sumberdaya manusia ( human resources ) dari daerah itu sendiri yang notabene akan lebih tahu apa yang dibutuhkan daerah tersebut" (Sumodiningrat, 2000:73)

Dalam rangka menyelenggarakan urusan rumah tangga daerah diperlukan adanya sumber-sumber pendapatan daerah yang strategis. Dalam hal ini salah satunya yang terpenting adalah pendapatan yang diperoleh dari pungutan retribusi daerah. Sebagai salah satu komponen Pendapatan Asli Daerah retribusi daerah memiliki prospek yang sangat baik untuk dikembangkan. Oleh sebab itu retribusi daerah harus bisa dikelola dengan profesional dan transparan dalam rangka 
optimalisasi dan usaha untuk meningkatkan kontribusinya terhadap Pendapatan Asli daerah (PAD). Sebagai salah satu sumber pendapatan asli daerah yang strategis, maka pemungutan retribusi daerah ini harus dilakukan secara berkala dan teratur dalam rangka melaksanakan peningkatkan pembangunan daerah. Hal ini dimaksudkan agar penerimaan pendapatan yang diperoleh dari pungutan pajak ini dapat mencapai target yang telah ditetapkan (Haerah, 2017).

Dari sekian banyak jenis retribusi daerah, yang sangat menarik diteliti khususnya di Kabupaten Jember adalah retribusi parkir. Penelitian ini sangat menarik karena sejumlah alasan sebagai berikut:

Pertama, Jember merupakan salah satu kabupaten terbesar di Provinsi Jawa Timur dengan jumlah kendaraan yang cukup banyak dan saat ini masih terus bertambah jumlahnya, namun sejauh ini belum memberikan kontribusi yang cukup besar terhadap penerimaan Pendapatan Asli Daerah Kabupaten Jember. Menurut data dari Dinas Pendapatan Daerah Kabupaten Jember bahwa pada tahun 2015 kontribusi retribusi parkir terhadap PAD Jember hanya sekitar 0,31\%. Jumlah ini tentunya masih sangat kecil jika dibandingkan dengan potensi yang bisa digali dari sektor retribusi daerah.

Kedua, Kabupaten Jember juga merupakan salah satu kabupaten terpadat penduduk dengan jumlah kendaraan yang cukup besar. Melihat potensi yang cukup besar tersebut, maka peluang Pemerintah Kabupaten Jember untuk meningkatkan Pendapatan Asli Daerah dari sektor retribusi parkir juga terbuka sangat lebar. Sayangnya, hingga saat ini strategi atau upaya-upaya peningkatan penerimaan daerah khususnya dari sektor retribusi belum dilakukan dengan baik dan maksimal. Padahal jika retribusi ini bisa digali lebih intensif dan dikelola secara lebih baik, tentunya potensi penerimaan retribusi dari sektor ini bisa memberikan kontribusi cukup besar terhadap Pendapatan Asli Daerah Jember.

Daerah Kabupaten Jember adalah salah satu daerah otonom dalam wilayah Negara Republik Indonesia, dalam usaha membiayai urusan rumah tangganya memperoleh sumber pendapatan dari pemerintahan pusat dan pemerintahan 
daerah itu sendiri. Sumber pendapatan yang berasal dari pusat adalah bantuanbantuan dan juga hasil perimbangan keuangan pusat dan daerah yang jumlahnya sangat fluktuatif. Oleh sebab itu, keinginan akan selalu meningkatnya Pendapatan Asli Daerah (PAD) merupakan kunci atas sukses dan berjalannya pembangunan sesuai dengan harapan masyarakatnya.

\subsection{Rumusan Masalah}

Berdasarkan uraian tersebut penelitian ini akan diarahkan untuk menjawab pertanyaan yang dirumuskan sebagai berikut:

1. Mengapa kontribusi penerimaan retribusi parkir relatif masih kecil terhadap Pendapatan Asli Daerah Jember?

2. Kendala apa saja yang dihadapi Pemerintah Kabupaten Jember dalam upaya meningkatkan pendapatan dari sektor retrbusi parkir?

\subsection{Tujuan dan Kegunaan Penelitian}

1. Untuk memberikan gambaran tentang kontribusi penerimaan retribusi parkir terhadap Pendapatan Asli Daerah Jember;

2. Untuk memberikan gambaran tentang kendala yang dihadapi Pemerintah Kabupaten Jember dalam upaya meningkatkan pendapatan dari sektor retrbusi parkir.

Sedangkan kegunaan penelitian ini antara lain:

1. Memberikan sumbangsih teori terhadap pengembangan ilmu pengetahuan khususnya bidang ilmu pemerintahan;

2. Memberikan sumbangan pemikiran terhadap instansi terkait di Kabupaten Jember tentang pentingnya manajemen pengelolaan retribusi parkir sehingga bisa meningkatkan pendapatan asli daerah dari sektor retribusi parkir;

3. Penelitian ini diharapkan juga bisa menjadi bahan referensi bagi peneliti selanjutnya yang ingi meneliti topik yang sama serta dapat digunakan sebagai penunjang kenaikan pangkat bagi dosen. 


\section{BAB 2. TINJAUAN PUSTAKA}

\subsection{Otonomi Daerah}

Otonomi daerah merupakan pembagian kekuasaan yang diberikan oleh pemerintah pusat kepada pemerintah daerah untuk mengurus dan mengatur daerahnya. Kekuasaan ini diberikan oleh pemerintah pusat agar pemerintah setiap daerah dapat dikontrol dengan mudah oleh pemerintah pusat. Pemerintah daerah memiliki kewajiban untuk bertanggung jawab kepada pemerintah pusat terhadap daerah yang diurus dan diaturnya. Ketentuan mengenai tanggung jawab pemerintah daerah kepada pemerintah pusat ini diatur di dalam UU (Kansil, dalam Khoirul Ifa, 2017 : 2).

Menurut UU No 32 Tahun 2004, otonomi daerah adalah hak, wewenang dan kewajiban dari daerah untuk mengurus dan mengatur sendiri urusan pemerintahan dan kepentingan dari masyarakat setempat sesuai dengan peraturan perundang-undangan. Dengan adanya otonomi daerah ini, diharapkan dapat mempermudah segala urusan pemerintahan, baik di tingkat pusat pemerintahan negara, maupun di tingkat pemerintahan daerah.

Pelaksanaan otonomi daerah di setiap kabupaten maupun kota dimulai dengan penyerahan wewenang (urusan) dari pemerintah pusat ke pemerintah daerah. Dengan adanya otonomi daerah setiap daerah dituntut lebih mandiri dalam hal pembiayaan, adapun sumber pembiayaan yang paling penting dalam APBD adalah pendapatan asli daerah (PAD) yang komponen utamanya berasal dari pajak daerah dan retribusi daerah. Dalam mewujudkan pelaksanaan otonomi daerah menurut Undang-Undang 32 tahun 2004 tentang pemerintahan daerah hendaknya pemerintah daerah berusaha lebih meningkatkan Pendapatan Asli Daerah unuk mengurangi ketergantungan daerah terhadap pusat. Salah satu langkah kongkrit yang dilakukan pemerintah daerah dalam meningkatkan PAD yaitu dengan meningkatkan pendapatan dari pajak dan retribusi daerah. Kedua komponen tersebut merupakan komponen utama dalam meningkatkan PAD disetiap daerah (Khoirul Ifa, $2017: 1$ ). 


\subsection{Anggaran Pendapatan dan Belanja Daerah}

Anggaran Pendapatan dan Belanja Daerah (APBD) adalah rencana keuangan tahunan daerah yang dibahas dan disetujui bersama oleh Pemerintah Daerah dan DPRD, dan ditetapkan dengan Peraturan Daerah. Jadi APBD menampung kepentingan publik dan digunakan dengan sebesar-besarnya kemakmuran masyarakat yang diwujudkan melalui beberapa program dan kegiatan pemerintah (Khoirul Ifa, $2017: 2$ ).

Halim, dkk dalam Khoirul Ifa (2017: 3) menyatakan APBD adalah rencana keuangan tahunan pemerintah daerah yang dibahas dan disetujui bersama oleh pemerintah daerah dan DPRD. Sementara itu Mardiasmo dalam Khoirul Ifa (2017 : 3) mengatakan, bahwa salah satu aspek penting dari pemerintah daerah yang harus diatur secara hati-hati adalah masalah pengelolaan keuangan dan anggaran daerah. Anggaran daerah yang tercermin dalam APBD merupakan instrumen kebijakan utama bagi pemerintah daerah, menduduki porsi sentral dalam upaya pengembangan kapabilitas dan efektivitas pemerintah daerah. Anggaran daerah seharusnya digunakan sebagai alat untuk menentukan besarnya pendapatan dan belanja, alat bantu pengambilan putusan dan perencanaan pembangunan serta alat otoritas pengeluaran di masa yang akan datang dan ukuran standar untuk mengevaluasi kinerja serta alat koordinasi bagi semua aktivitas pada berbagai unit kerja.

Badrudin dalam Khoirul Ifa (2017 : 3) berpendapat APBD adalah suatu rencana kerja pemerintah daerah yang mencakup seluruh pendapatan atau penerimaan dan belanja atau pengeluaran pemerintah daerah baik provinsi, kabupaten, dan kota dalam rangka mencapai sasaran pembangunan dalam kurun waktu satu tahun yang dinyatakan dalam satuan uang dan disetujui oleh DPRD dalam peraturan perundangan yang disebut peraturan daerah. 


\subsection{Pendapatan Asli Daerah}

Sebagaimana menurut Undang-Undang Republik Indonesia Nomor 33 Tahun 2004 tentang Perimbangan Keuangan antara Pemerintah Pusat dan Pemerintahan Daerah menyatakan Pendapatan Asli Daerah, selanjutnya disebut PAD adalah pendapatan yang diperoleh Daerah yang dipungut berdasarkan Peraturan Daerah sesuai dengan peraturan perundang-undangan.

Sedangkan menurut Mardiasmo dalam Khoirul Ifa (2017 : 3) PAD adalah penerimaan daerah dari sektor pajak daerah, retribusi daerah, hasil perusahaan milik daerah, hasil pengelolaan kekayaan daerah yang dipisahkan dan lain-lain pendapatan asli daerah yang sah. Jadi pendapatan asli daerah adalah merupakan penerimaan yang diperoleh dari daerah sendiri melalui upaya-upaya daerah untuk meningkatkan kas daerah sehingga ketergantungan pemerintah daerah terhadap pemerintah pusat dapat diminimalisir.

Menurut Mardiasmo dalam Khoirul Ifa (2017 : 3) pemerintah diharapkan dapat meningkatkan PAD untuk mengurangi ketergantungan terhadap pembiayaan dari pusat, sehingga meningkatkan otonomi dan keleluasaan daerah (local discretion). Lanjutnya, langkah penting yang harus dilakukan pemerintah daerah untuk meningkatkan penerimaan daerah adalah menghitung potensi Pendapatan Asli Daerah (PAD) yang riil dimiliki daerah.

Undang-Undang Nomor 32 Tahun 2004 tentang Pemerintah Daerah sebagai pengganti Undang-Undang Nomor 22 Tahun 1999, memang memberikan dampak luas pada pelaksanaan Pemerintahan di daerah. Konsep dasar Undang-Undang tersebut berpijak pada pasal 18 UUD 1945, dimana prinsip negara kesatuan dipegang teguh. Penerapan azas desentralisasi dan dekosentrasi dilaksanakan bersama-sama dengan memberi bobot lebih luas pada desentralisasi. Implikasinya, timbul kewenangan dan kewajiban lebih luas bagi daerah untuk melaksanakan berbagai kegiatan pemerintahan secara lebih mandiri dalam mengurus rumah tangganya. Yang terpenting adalah dukungan kemampuan daerah terhadap keberadaannya sebagai daerah otonom, yaitu kaitan antara 
kewenangan yang dimiliki serta sumber keuangan daerah yang menjadi daerah (Nurhadi dan Asir, 2004:100).

Gambaran kemampuan daerah dalam menjalankan fungsi utamanya tersebut diatur dalam UU No. 32 Tahun 2004, yang menyatakan daerah berhak atas sumber-sumber penerimaan berupa :

1. Pendapatan Asli Daerah ( PAD )

2. Dana Perimbangan Keungan Pusat-Daerah

3. Lain-lain penerimaan yang sah.

Sedang Pendapatan Asli Daerah ( PAD ) terdiri dari :

1. Hasil pajak Daerah

2. Restribusi Daerah

3. Perusahaan Daerah dan hasil pengelolaan kekayaan daerah lainya yang dipisahkan.

4. Dan lain-lain Pendapatan Asli Daerah yang sah.

Daerah melaksanakan wewenang UU No. 32 thn 2004, daerah melakukan upaya positif untuk meningkatkan Pendapatan Asli Daerah (PAD) melalui :

1. Intensifikasi, yaitu melalui pendapatan dan peremajaan obyek dan subyek pajak serta restribusi daerah, mempelajari kembali kembali pajak daerah yang dipangkas guna mengisi kemungkinan untuk dialihkan menjadi restribusi, intensifikasi penerimaan restribusi daerah, memperbaiki sarana dan prasrana pungutan yang belum memadai.

2. Ekstensifikasi, yaitu melalui penggalian sumber penerimaan baru.

3. Peningkatan pelayanan kepada masyarakat.

Adapun sumber-sumber keuangan daerah sebenarnya ada tiga jenis yaitu uang dekosentrasi (yaitu dari APBN dulu diserahkan kepada Kanwil dengan spesific grant, sekarang berubah block grant kepada dinas), uang desentralisasi, dan uang pembatuan, yang harus mampu dikreatifkan lagi melalui Perda, yang merupakan produk politik lokal, yang penting masyarakat dapat merasakan manfaatnya, sehingga memberikan ruang yang lebih luas bagi penciptaan nilai 
tambah, pembiayaan, serta penerimaan daerah. Salah satu perubahan penting dalam melihat potensi dan dinamika perekonomian daerah adalah Pendapatan Asli Daerah ( PAD ).

Kabupaten Jember, yang menduduki posisi ke-empat penerima Pendapatan Asli Daerah ( PAD ) terbesar setelah Surabaya, Sidoarjo dan Malang memiliki kekuatan potensi yang sejajar dengan daerah-daerah penyangga Surabaya. Struktur Pendapatan Asli Daerah (PAD) Kabupaten Jember didominasi oleh Restribusi daerah (sebagian besar dari restribusi kesehatan), pajak daerah, penerimaan lain-lain, dan bagian laba Badan Usaha Milik Daerah (Nurhadi dan Asir, 2004:100).

\subsection{Retribusi Daerah}

Restribusi daerah merupakan salah satu unsur penting penunjang Pendapatan Asli Daerah yang cukup signifikan untuk peningkatan pembangunan. Restribusi adalah pungutan dari pemerintah kepada orang atau badan hukum, sedang orang atau badan hukum tersebut mendapat keuntungan tertentu yang biasanya adalah bisa dinikmati atau diperoleh dengan cepat. Persoalan yang sering muncul adalah mental peratur daerah itu sendiri dalam menentukan dan mengelola peluang-peluang yang bisa dikenakan restribusi.

Sedangkan menurut UU nomor 28 tahun 2009 Retribusi Daerah, yang selanjutnya disebut Retribusi adalah pungutan daerah sebagai pembayaran atas jasa atau pemberian izin tertentu yang khusus disediakan dan/atau diberikan oleh Pemerintah Daerah untuk kepentingan orang pribadi atau Badan.

Menurut Undang-Undang Nomor 28 tahun 2009 secara keseluruhan terdapat 30 jenis retribusi yang dapat dipungut oleh daerah yang dikelompokkan menjadi 3 yaitu :

1. Retribusi Jasa Umum

Menurut UU No. 28 Tahun 2009 Pasal 109 menyatakan bahwa Retribusi yang dikenakan atas jasa umum digolongkan sebagai Retribusi Jasa Umum. 
Objek Retribusi Jasa Umum adalah pelayanan yang disediakan atau diberikan Pemerintah Daerah untuk tujuan kepentingan dan kemanfaatan umum serta dapat dinikmati oleh orang pribadi atau badan. Menurut UU No. 28 Tahun 2009 Pasal 110 Jenis Retribusi Jasa Umum adalah:

a. Retribusi Pelayanan Kesehatan;

b. Retribusi Pelayanan Persampahan/Kebersihan;

c. Retribusi Penggantian Biaya Cetak KTP dan Akta Catatan Sipil;

d. Retribusi Pelayanan Pemakaman Dan Pengabuan Mayat;

e. Retribusi Pelayanan Parkir Di Tepi Jalan Umum;

f. Retribusi Pelayanan Pasar;

g. Retribusi Pengujian Kendaraan Bermotor;

h. Retribusi Pemeriksaan Alat Pemadam Kebakaran;

i. Retribusi Penggantian Biaya Cetak Peta;

j. Retribusi Penyediaan Dan/Atau Penyedotan Kakus;

k. Retribusi Pengolahan Limbah Cair;

1. Retribusi Pelayanan Tera/Tera Ulang

m. Retribusi Pelayanan Pendidikan; dan

n. Retribusi Pengendalian Menara Telekomunikasi.

2. Retribusi Jasa Usaha

Menurut UU No.28 Tahun 2009 Pasal 126 menyatakan bahwa Retribusi yang dikenakan atas jasa usaha digolongkan sebagai Retribusi Jasa Usaha. Objek Retribusi Jasa Usaha adalah pelayanan yang disediakan oleh Pemerintah Daerah dengan menganut prinsip komersial yang meliputi: (1) Pelayanan dengan menggunakan/memanfaatkan kekayaan Daerah yang belum dimanfaatkan secara optimal; dan/atau (2) Pelayanan oleh Pemerintah daerah sepanjang belum disediakan secara memadai oleh pihak swasta. Menurut UU No.28 Tahun 2009 Pasal 127 Jenis Retribusi Jasa Usaha adalah:
a. Retribusi Pemakaian Kekayaan Daerah;
b. Retribusi Pasar Grosir Dan/Atau Pertokoan; 
c. Retribusi Tempat Pelelangan;

d. Retribusi Terminal;

e. Retribusi Tempat Khusus Parkir;

f. Retribusi Tempat Penginapan/Pesanggrahan/Villa

g. Retribusi Rumah Potong Hewan;

h. Retribusi Pelayanan Kepelabuhan;

i. Retribusi Tempat Rekreasi Dan Olahraga;

j. Retribusi Penyeberangan Di Air; dan

k. Retribusi Penjualan Produksi Usaha Daerah.

3. Perizinan Tertentu

Menurut UU No.28 Tahun 2009 Pasal 140 menyatakan bahwa Retribusi yang dikenakan atar perizinan tertentu digolongkan sebagai Retribusi Perizinan Tertentu. Objek Retribusi Perizinan Tertentu adalah pelayanan perizinan tertentu oleh Pemerintah daerah kepada orang pribadi atau Badan yang dimaksudkan untuk pengaturan dan pengawasan atas kegiatan pemanfaatan ruang, penggunaan sumber daya alam, barang, prasarana, sarana fasilitas tertentu guna melindungi kepentingan umum dan menjaga kelestarian lingkungan. Menurut UU No. 28 Tahun 2009 Pasal 141 Jenis Retribusi Perizinan Tertentu adalah:

a. Retribusi Izin Mendirikan Bangunan;

b. Retribusi Izin Tempat Penjualan Minuman Beralkhohol;

c. Retribusi Izin Gangguan;

d. Retribusi Izin Trayek; dan

e. Retribusi Izin Usaha Perikanan

Subjek Retribusi Daerah (Mardiasmo 2011:18) adalah sebagai berikut:

1. Retribusi Jasa Umum adalah orang pribadi atau badan yang menggunakan/menikmati pelayanan jasa umum yang bersangkutan.

2. Retribusi Jasa Usaha adalah orang pribadi atau badan yang menggunakan/menikmati pelayanan jasa usaha yang bersangkutan. 
3. Retribusi Perizinan Tertentu adalah orang pribadi atau badan yang memperoleh izin tertentu dari Pemerintah Daerah.

\subsection{Retribusi Parkir}

Pembangunan merupakan proses multi dimensional yang melibatkan perubahan-perubahan mendasar terhadap struktur sosial, sikap masyarakat, percepatan pertumbuhan ekonomi, pengurangan ketidakmerataan, dan pemberantasan kemiskinan. Menurut bahwa pembangunan ditandai dengan adanya perubahan terhadap struktur masyarakat yang berasal dari kemampuan masyarakat sendiri yang meliputi lima rangkaian kegiatan yang tidak terpisahkan, yaitu : kesempatan kerja, penghasilan, tabungan, modal dan produksi.

Dalam pembangunan yang makin berkembang, masyarakat memainkan peran sentral sebgai subyek bukan obyek pembangunan, artinya masyarakatlah yang menentukan jalannya pembangunan ataupun keberhasilannya. Semua elemen bergerak seiring sejalan dalam upaya mewujudkan masyarakat yang maju, mandiri, dan sejahtera dalam suasana yang berkeadilan. Pembangunan yang demikian adalah pembangunan dari, oleh dan untuk masyarakat (Nurhadi dan Asir, 2004:101).

Anggaran Pendapatan dan Belanja Daerah ( APBD ) sebagai infrastruktur ekonomi pembangunan, yang merupakan akumulasi modal dari partisipasi masyarakat daerah yang digambarkan lewat Pendapatan Asli Daerah ( PAD ) merupakan tulang punggung dari pada modal pembangunan itu sendiri, yang salah satunya adalah restribusi lahan parkir. Retribusi parkir yang selama ini dikenakan pada para pengguna jasa kendaraan bermotor merupakan salah satu jenis pemasukan yang tidak bisa dipandang sebelah mata. Selain itu persoalan parkir yang sering mengundang persoalan sosial yang berlatar belakang ekonomi (parkir liar/pak ogah) perlu ditangani secara profesional agar tidak menimbulkan ekses negatif di masyarakat. 
Berbicara tentang sebuah produk hukum yang mengatur tentang masyarakat yang dikenai hukum dengan melibatkannya secara aktif adalah sebuah langkah strategis yang harus dilakukan, sehingga ketika sebuah produk hukum itu disyahkan dan diberlakukan dapat diterima dan dipatuhi bersama sebagai konsekwensi logis atas dibuatnya produk hukum untuk mengatur kehidupannya. Berangkat dari hal tersebut diatas maka keberatan-keberatan yang diatur secara normatif penyampaiannya (keberatan masyarakat atas sebuah produk hukum) benar-benar dapat dipertanggungjawabkan sebagai partisipasi aktif masyarakat dalam kehidupan berbangsa dan bernegara (Nurhadi dan Asir, 2004:104).

Berdasarkan Pasal 4 Peraturan Daerah Kabupaten Jember No. 12 Tahun 2008 Tentang Retribusi Parkir Kabupaten Jember bahwa Retribusi parkir dibedakan menjadi 3 (tiga) :

1. Retribusi Parkir Berlangganan adalah retribusi parkir yang dipungut untuk jangka waktu 1 (satu) tahun atau sama dengan masa berlakunya pajak kendaraan bermotor sebagai pembayaran atas penyediaan dan atau pelayanan tempat parkir di tepi jalan umum yang disediakan oleh pemerintah kabupaten.

2. Retribusi Parkir Harian adalah retribusi parkir yang dipungut sebagai pembayaran atas pelayanan penyediaan setiap 1 (satu) kali parkir pada tempat parkir di tepi jalan umum atau tempat lain yang disediakan oleh pemerintah kabupaten.

3. Retribusi Parkir Jalur Panjang adalah retribusi parkir yang dipungut untuk kendaraan di dalam terminal sebagai pembayaran atas pelayanan tempat parkir selain kendaraan penumpang yang dikenakan retribusi atau kendaraan penumpang yang sedang menunggu pemberangkatan.

Selanjutnya menurut Pasal 5 Peraturan Daerah Kabupaten Jember No. 12 Tahun 2008 bahwa Obyek Retribusi adalah pelayanan penyediaan tempat parkir di tepi jalan umum dan atau untuk tempat lain yang disediakan oleh pemerintah kabupaten. Sedangkan pasal 6 menyebutkan bahwa Subyek Retribusi 
Parkir Kendaraan adalah orang pribadi atau badan hukum yang memiliki Kendaraan Bermotor yang mendapatkan pelayanan parkir di tepi jalan umum dan atau di tempat lain yang disediakan oleh pemerintah kabupaten.

Berdasarkan pasal 12 Peraturan Daerah Kabupaten Jember No. 12 Tahun 2008 bahwa struktur dan besaran tarif retribusi didasarkan atas tujuan untuk mengendalikan dan memperlancar lalu lintas jalan dengan mempertimbangkan biaya penyelenggaraan pelayanan parkir dengan mengukur kemampuan masyarakat dan aspek keadilan.

Selanjutnya menurut pasal 13 disebutkan bahwa struktur besaran tarif retribusi parkir 1 (satu) kendaraan ditetapkan sebagai berikut :

1. Tarif Retribusi Parkir Berlangganan untuk 1 (satu) tahun ;

a. Kendaraan Bermotor roda 2 (dua) atau roda 3 (tiga) sebesar Rp 20.000,00 (dua puluh ribu rupiah);

b. Kendaraan Bermotor roda 4 (empat) sebesar Rp 40.000,00 (empat puluh ribu rupiah);

c. Kendaraan Bermotor dengan roda 6 (enam) / lebih sebesar Rp 50.000,00 (lima puluh ribu rupiah);

d. Kendaraan Bermotor jenis Angkutan Barang roda 4 (empat) dan jenis taksi argo sebesar Rp 25.000,00 (dua puluh lima ribu rupiah).

2. Tarif Retribusi parkir harian setiap satu kali parkir :

a. Kendaraan Bermotor roda 2 (dua) dan roda 3 (tiga) sebesar Rp 500,00 (lima ratus rupiah).

b. Kendaraan Bermotor beroda 4 (empat) / lebih sebesar Rp 1.000,00 (seribu rupiah).

c. Kendaraan Bermotor dengan roda 6 (enam) / lebih sebesar Rp 2.500,00 (dua ribu lima ratus rupiah).

3. Tarif Retribusi Parkir Insidentil :

a. Kendaraan Bermotor roda 2 (dua) dan 3 (tiga) sebesar Rp 750,00 (tujuh ratus lima puluh rupiah). 
b. Kendaraan Bermotor roda 4 (empat)/ lebih sebesar Rp 1.500,00 (seribu lima ratus rupiah).

c. Kendaraan Bermotor dengan roda enam (enam) / lebih sebesar Rp 3.000,00 (tiga ribu rupiah).

Tentang tata cara pemungutan retribusi parkir menurut pasal 14 Peraturan Daeerah Kabupaten Jember No. 12 Tahun 2008 dijelaskan sebagai berikut:

1. Pemungutan retribusi parkir berlangganan dilaksanakan di Kantor Bersama dengan Sistim Administrasi Manunggal di Bawah Satu Atap (SAMSAT) pada loket tersendiri di luar mekanisme pelayanan Samsat.

2. Pemungutan retribusi parkir berlangganan dilakukan bersamaan pada saat Subyek Retribusi melakukan pembayaran pajak Kendaraan Bermotor di Kantor Samsat.

3. Pelunasan atas retribusi parkir berlangganan diberikan bukti tanda pelunasan pembayaran retribusi parkir berlangganan dan diberi tanda khusus/stiker untuk dipasang/ditempel pada kendaraan wajib retribusi.

4. Mekanisme pemungutan retribusi parkir berlangganan akan diatur lebih lanjut dengan Peraturan Bupati.

Lebih lanjut dalam pasal 15 Peraturan Daerah Kabupaten Jember No. 12 Tahun 2008dijelaskan bahwa: (1) Retribusi parkir harian sebagaimana dipungut di tempat pelayanan parkir oleh juru parkir. (2) Juru Parkir memungut retribusi Parkir Harian dengan menggunakan karcis parkir sesuai tarif yang tertera di dalamnya. (3) Wajib Retribusi Parkir yang telah membayar Retribusi Parkir Berlangganan, setiap kali parkir tidak dikenakan lagi pemungutan retribusi parkir, kecuali masa jangka waktu retribusi parkir berlangganan telah habis masa berlakunya. (4) Pemungutan retribusi parkir untuk kendaraan yang tidak terdaftar di Kantor Bersama Samsat Kabupaten dan kendaraan yang tidak dapat menunjukan bukti bayar parkir berlangganan (bukti stiker atau bukti lain yang sah) dikenakan retribusi parkir di tepi jalan umum yang dipungut oleh juru parkir. 
Terkait dengan hasil pemungutan retribusi parkir disebutkan dalam Pasal 16 bahwa: (1) Hasil pemungutan retribusi parkir setiap hari disetor ke Kas Umum Daerah. (2) Penyetoran dilakukan dalam waktu 1 x 24 jam dengan menggunakan form yang telah ditetapkan.

\section{BAB 3. METODE PENELITIAN}

\subsection{Jenis Penelitian}

Penelitian ini dapat dikatakan sebagai metode penulisan deskriptif kuantitatif dengan metode pendekatan berfikir kualitatif. Ciri-ciri penelitian deskriptif ini adanya sifat-sifat tertentu yang pada umumnya terdapat dalam metode deskriptif sehingga dapat dipandang sebagai ciri yang memusatkan pada pemecahan masalah yang ada pada masa sekarang. Sebagai penulisan deskriptif, penelitian ini termasuk studi operasional (Action Research) yang terkenal dan berkembang sebagai teknik penelitian terutama di bidang sosial.

\subsection{Metode Pengumpulan Data}

Ada dua (2) metode yang digunakan untuk mengumpulkan data penelitian ini, yaitu metode dokumentasi dan studi literatur. Pengumpulan data dengan metode dokumentasi dan dilakukan dengan memanfaatkan dokumen elektronik atau catatan tertulis, termasuk juga arsip-arsip. Untuk dokumen elektronik peneliti memanfaatkan hasil wawancara yang dilakukan oleh para wartawan dan dimuat di beberapa website. Sedangkan untuk studi literatur peneliti memanfaatkan berbagai literatur, buku-buku atau jurnal yang berkaitan dengan retribusi parkir dan pajak daerah.

\subsection{Metode Analisa Data}

Metode analisa data yang digunakan dalam penelitian ini adalah metode deskriptif kuantitatif, yaitu metode yang dilakukan dengan cara menganalisa 
semua data berupa angka-angka penerimaan retribusi dengan menggunakan logika berfikir. Proses analisis data dilakukan dengan menyajikan temuan data atau informasi sesuai dengan tujuan penelitian ini. Data disajikan dalam bentuk tabel yang langsung disertai dengan penjelasan interprestasi data.

\section{BAB IV. HASIL PENELITIAN DAN PEMBAHASAN}

\subsection{Gambaran Umum Kabupaten Jember}

\subsubsection{Kondisi Geografis Kabupaten Jember}

Kabupaten Jember secara astronomis terletak pada posisi 6 $27^{\circ} 29^{\prime \prime}$ s/d 7²14'35" Bujur Timur dan 759'6" s/d 833'56" Lintang Selatan dengan luas wilayah seluas $3.293,34 \mathrm{Km}^{2}$. dan memiliki \pm 76 pulau-pulau kecil dengan pulau terbesar adalah Pulau Nusa Barong. Berdasarkan posisi geografisnya, Kabupaten Jember memiliki batas Sebelah Utara: Kabupaten Bondowoso, dan Kabupaten Probolinggo, Sebelah Selatan: Samudera Indonesia, Sebelah Timur: Kabupaten Banyuwangi, Sebelah Barat: Kabupaten Lumajang. Penggunaan lahan di Kabupaten Jember didominasi oleh fungsi kegiatan budidaya, dimana lahan yang dibudidayakan untuk pertanian adalah seluas 46,41 \% dari luas wilayah, sedangkan sisanya digunakan untuk permukiman seluas $9,93 \%$, hutan seluas $21,17 \%$ dan lain-lain seluas $22,49 \%$.

\subsubsection{Kondisi Topografis}

Kabupaten Jember berada pada ketinggian 0 - 3.330 meter di atas permukaan laut. Daerah dengan ketinggian 100 - 500 meter di atas permukaan air laut merupakan kawasan terluas, yaitu $1.240,77 \mathrm{~km}^{2}$ atau $37,68 \%$ dari luas wilayah Kabupaten Jember sedangkan kawasan tersempit adalah daerah dengan ketinggian lebih dari 2.000 meter di atas permukaan laut dengan luas $31,34 \mathrm{~km}^{2}$ atau $0,95 \%$ dari luas wilayah Kabupaten Jember. Kabupaten Jember memiliki karakter topografi dataran ngarai yang subur pada bagian Tengah dan Selatan 
serta dikelilingi oleh pegunungan yang memanjang pada batas Barat dan Timur. Di wilayah Barat Daya memiliki dataran dengan ketinggian $0-25$ meter di atas permukaan laut, sedangkan di wilayah Timur Laut yang berbatasan dengan Kabupaten Bondowoso dan wilayah Tenggara yang berbatasan dengan Kabupaten Banyuwangi memiliki ketinggian di atas 1.000 meter di atas permukaan air laut.

\subsubsection{Kependudukan}

Secara administratif Kabupaten Jember terbagi dalam 31 (tiga puluh satu) wilayah Kecamatan dan terdiri dari 247 (dua ratus empat puluh tujuh) wilayah desa dan kelurahan.

Tabel 4.1 Jumlah Penduduk Kabupaten Jember Tahun 2015

\begin{tabular}{|l|r|r|c|}
\hline \multirow{2}{*}{ Kecamatan } & \multicolumn{2}{|c|}{ Jumlah Penduduk } & \multirow{2}{*}{ Total } \\
\cline { 2 - 3 } & Laki-laki & Perempuan & \\
\hline Jember & 1.192 .791 & 1.141 .649 & 2.334 .440 \\
\hline Jombang & 28.584 & 27.349 & 55.933 \\
\hline Kencong & 32.830 & 31.530 & 64.360 \\
\hline Sumberbaru & 56.718 & 54.481 & 111.199 \\
\hline Gumukmas & 42.863 & 40.592 & 83.455 \\
\hline Umbulsari & 36.353 & 34.631 & 70.984 \\
\hline Tanggul & 42.564 & 40.817 & 83.381 \\
\hline Semboro & 23.825 & 22.904 & 46.729 \\
\hline Puger & 58.029 & 54.497 & 112.526 \\
\hline Bangsalsari & 59.293 & 57.535 & 116.828 \\
\hline Balung & 39.515 & 38.032 & 77.547 \\
\hline Wuluhan & 59.478 & 55.271 & 114.749 \\
\hline Ambulu & 55.423 & 51.526 & 106.949 \\
\hline Rambipuji & 41.704 & 39.998 & 81.702 \\
\hline Panti & 29.488 & 27.779 & 57.267 \\
\hline Sukorambi & 17.710 & 16.815 & 34.525 \\
\hline Jenggawah & 40.200 & 37.655 & 77.855 \\
\hline Ajung & 37.900 & 35.652 & 73.552 \\
\hline
\end{tabular}




\begin{tabular}{|l|r|r|r|}
\hline Tempurejo & 37.266 & 34.123 & 71.389 \\
\hline Kaliwates & 59.572 & 58.478 & 118.050 \\
\hline Patrang & 47.801 & 46.656 & 94.457 \\
\hline Sumbersari & 63.346 & 62.486 & 125.832 \\
\hline Arjasa & 17.678 & 16.970 & 34.648 \\
\hline Mumbulsari & 31.366 & 30.044 & 61.410 \\
\hline Pakusari & 19.289 & 18.818 & 38.107 \\
\hline Jelbuk & 14.427 & 13.770 & 28.197 \\
\hline Mayang & 22.451 & 22.001 & 44.452 \\
\hline Kalisat & 35.733 & 34.355 & 70.088 \\
\hline Ledokombo & 30.990 & 30.765 & 61.755 \\
\hline Sukowono & 27.768 & 27.041 & 54.809 \\
\hline Silo & 56.040 & 53.743 & 109.783 \\
\hline Sumberjambe & 25.597 & 25.335 & 50.932 \\
\hline Sumber $:$ BPS Kabur & & & \\
\hline
\end{tabular}

Sumber : BPS Kabupaten Jember

Penduduk Kabupaten Jember pada tanun 2015 sebanyak 2.334.440 jiwa yang terdiri dari laki-laki 1.192 .791 jiwa dan perempuan sebanyak 1.141.649 dengan sex rasio 195. Rasio jenis kelamin sebesar 195, artinya terdapat 195 laki-laki untuk setiap 100 perempuan. Komposisi ini menunjukkan jumlah penduduk laki-laki dan perempuan yang tidak seimbang. Kondisi seperti ini diharapkan memiliki tingkat produktivitas yang tinggi. Penduduk Kabupaten Jember menurut data statistik tahun 2015 berjumlah 2.334.440 Jiwa.

Ditinjau dari mata pencaharian penduduknya yang sebagian besar masyarakat Kabupaten Jember bermata pencaharian sebagai petani dan atau buruh tani. Hal ini terbukti dengan besarnya jumlah penduduk yang berdomisili di wilayah pedesaan. Kondisi struktur tanah Kabupaten Jember rata-rata berjenis tanah persawahan dan perkebunan bahkan bisa dikatakan ibu kota Kabupaten Jember dikelilingi oleh perkebunan di wilayah utara dan timur yang membujur dari arah barat samapi timur dan dari timur sampai ke arah selatan sedangkan wilayah barat dan selatan dipenuhi dengan persawahan. Memperhatikan suburnya tanah perkebunan dan persawahan di wilayah 
pedesaan hal ini ditunjang oleh pengairan yang cukup dari aliran sungai maupun anak sungai yang melintasi di sepanjang wilayah pedesaan, lebih-lebih bila musim hujan tiba airpun meluap memenuhi sungai-sungai tersebut.

\subsubsection{Perekonomian}

Jika dikaitkan dengan koridor pertumbuhan ekonomi Jawa Timur, Kabupaten Jember termasuk koridor timur yang tergolong daerah maju dengan basis produksi di sektor primer (pertanian), khususnya tembakau dan hasil perkebunan serta hasil produksi pertanian lainnya disamping hasil industri kecil yang berbasis pertanian, sehingga kontribusi dalam peningkatan PDRB bergerak lamban dan masih memerlukan dukungan alokasi dana pemerintah pusat dalam mendorong laju pertumbuhan ekonominya.

Tabel 4.2 Realisasi APBD Jember 5 Tahun Terakhir

\begin{tabular}{|c|c|c|c|c|c|c|}
\hline No & Anggaran & $n-4$ & $n-3$ & $\mathrm{n}-2$ & $n-1$ & $\mathrm{n}$ \\
\hline (a) & (b) & (c) & (d) & (e) & (f) & (g) \\
\hline A & Pendapatan & & & & & \\
\hline 1 & $\begin{array}{l}\text { Pendapatan } \\
\text { Asli Daerah } \\
\text { (PAD) }\end{array}$ & $113,471,599,896.00$ & $108,808,347,550.00$ & $146,452,637,701.60$ & $178,000,599,064.49$ & $211,617,937,615.15$ \\
\hline 2 & $\begin{array}{l}\text { Dana } \\
\text { Perimbangan } \\
\text { (transfer) }\end{array}$ & $1,073,953,107,885.03$ & $1,079,600,625,225.99$ & $1,116,208,106,255.99$ & $1,108,201,773,138.00$ & $1,514,689,161,831.00$ \\
\hline 3 & $\begin{array}{l}\text { Lain-lain } \\
\text { Pendapatan } \\
\text { yang sah }\end{array}$ & $60,767,941,780.00$ & $60,185,037,680.00$ & $111,931,837,450.14$ & $174,253,288,729.00$ & $291,198,943,040.00$ \\
\hline & $\begin{array}{l}\text { Jumlah } \\
\text { Pendapatan }\end{array}$ & $1,248,192,649,561.03$ & $1,248,594,010,455.99$ & $1,374,592,581,407.73$ & $1,460,455,660,931.49$ & $2,017,506,042,486.15$ \\
\hline $\mathrm{B}$ & Belanja & & & & & \\
\hline 1 & $\begin{array}{l}\text { Belanja Tidak } \\
\text { Langsung }\end{array}$ & $755,609,791,407.13$ & $769,432,131,310.26$ & $1,078,287,653,361.00$ & $1,056,771,282,402.01$ & $1,279,517,962,584.00$ \\
\hline 2 & $\begin{array}{l}\text { Belanja } \\
\text { Langsung }\end{array}$ & $568,629,089,327.00$ & $520,187,274,818.00$ & $320,855,524,562.00$ & $458,011,349,343.00$ & $835,993,174,788.00$ \\
\hline 3 & $\begin{array}{l}\text { Jumlah } \\
\text { Belanja }\end{array}$ & $1,324,238,880,734.13$ & $1,289,619,406,128.26$ & $1,399,143,177,923.00$ & $1,514,782,631,745.01$ & $2,115,511,137,372.00$ \\
\hline & $\begin{array}{l}\text { Surplus/Defisit } \\
\text { Anggaran }\end{array}$ & $(76,046,231,173.10)$ & $(41,025,395,672.27)$ & $(24,550,596,515.27)$ & $(54,326,970,813.52)$ & $(98,005,094,885.85)$ \\
\hline
\end{tabular}

Kondisi perekonomian suatu daerah dapat dilhat dari indikator ekonomi daerah dengan Produk Domestik Regional Bruto (PDRB), Pendapatan Asli Daerah dan Pertumbuhan Ekonomi. Produk Domestik Regional Bruto 
(PDRB) adalah jumlah nilai produk barang dan jasa akhir yang dihasilkan oleh berbagai unit produksi pada suatu wilayah/daerah dalam jangka waktu tertentu. PDRB yang digunakan adalah PDRB atas dasar harga berlaku.

Tabel 4.3 Data Perekonomian Umum Kabupaten Jember 5 tahun terakhir

\begin{tabular}{|r|l|c|c|c|c|c|}
\hline No & \multicolumn{1}{|c|}{ Deskripsi } & $\mathrm{n}-4$ & $\mathrm{n}-3$ & $\mathrm{n}-2$ & $\mathrm{n}-1$ & $\mathrm{n}$ \\
\hline$(1)$ & \multicolumn{1}{|c|}{$(2)$} & $(3)$ & $(4)$ & $(5)$ & $(6)$ & $(7)$ \\
\hline \hline 1 & $\begin{array}{l}\text { PDRB harga konstan } \\
\text { Struktur perekonomian (Rp) }\end{array}$ & $9,783,828,130,000.00$ & $10,326,735,610,000.00$ & $24,518,550,060,000.00$ & & \\
\hline 2 & $\begin{array}{l}\text { Pendapatan perkapita } \\
\text { kabupaten/kota (Rp) }\end{array}$ & $8,277,230.00$ & $9,198,010.00$ & $9,681,440.00$ & & \\
\hline & $\begin{array}{l}\text { Upah minimum regional } \\
\text { kabupaten/kota (Rp) }\end{array}$ & $645,000.00$ & $770,000.00$ & $875,000.00$ & $920,000.00$ & $920,000.00$ \\
\hline 4 & Inflasi (\%) & $11,10 \%$ & $5,72 \%$ & $7,87 \%$ & $0.00 \%$ & $0.00 \%$ \\
\hline 5 & Pertumbuhan ekonomi (\%) & $6,04 \%$ & $5,5 \%$ & $6,04 \%$ & $0.00 \%$ & $0.00 \%$ \\
\hline & & & & & & \\
\hline
\end{tabular}

Sumber: PDRB kabupaten Jember

\subsection{Target dan Realisasi Pendapatan Asli Daerah Kabupaten Jember Tahun 2010-2015}

Perkembangan target dan realisasi Pendapatan Asli Daerah Kabupaten Jember dalam kurun waktu 2011-2016 dapat dilihat pada tabel berikut ini.

Tabel 4.4 Target dan Realisasi Pendapatan Asli Daerah Kabupaten Jember Tahun 2010-2016

\begin{tabular}{|c|c|c|c|c|}
\hline \multirow{2}{*}{ No } & \multirow{2}{*}{ Target } & Realisasi & \multicolumn{2}{|c|}{ Selisih } \\
\cline { 4 - 5 } & & & $(\mathrm{Rp})$ & $\%$ \\
\hline 2010 & $1.532 .635 .878 .256,60$ & $1.542 .834 .970 .274,43$ & $-10.199 .092 .017,83$ & 100,65 \\
\hline 2011 & $1.854 .046 .009 .772,32$ & $1.882 .586 .732 .606,79$ & $-28.540 .722 .834,47$ & 101,51 \\
\hline 2012 & $2.110 .026 .697 .225,31$ & $2.146 .090 .218 .860,72$ & $-36.063 .521 .635,41$ & 101,7 \\
\hline 2013 & $2.378 .574 .220 .186,50$ & $2.366 .375 .217 .230,67$ & $12.199 .002 .955,83$ & 99,49 \\
\hline 2014 & $2.836 .047 .816 .784,00$ & $2.798 .612 .164 .201,69$ & $37.435 .652 .582,31$ & 98,68 \\
\hline 2015 & $3.207 .302 .051 .757,00$ & $3.116 .542 .849 .533,93$ & $90.759 .202 .223,07$ & 97,17 \\
\hline
\end{tabular}

Sumber : Dinas Pendapatan Daerah Kabupaten Jember, Diolah, 2017

Berdasarkan tabel 4.4 di atas menunjukkan bahwa selama kurun waktu 2010 - 2015 realisasi Pendapatan Asli Daerah Kabupaten Jember cenderung fluktuatif. Pada kurun waktu 2010 - 2012 misalnya, Pendapatan Asli Daerah 
melebihi target yang ditetapkan. Sedangkan dalam kurun tahun 2013 - 2015 realisasi Pendapatan Asli Daerah kabupaten jember tidak melebihi target yang ditetapkan. Adanya peningkatan PAD di kabupaten jember ini menunjukkan telah terjadi peningkatan pada seluruh unsur PAD, baik dari pajak daerah, retribusi daerah, dan komponen pendapatan daerah lainnya yang sah.

\subsection{Target dan Realisasi Retribusi Daerah Terhadap Pendapatan Asli daerah Kabupaten Jember}

Retribusi daerah merupakan pungutan daerah atas pemberian izin dan pembayaran jasa tertentu yang khusus diberikan dan disediakan oleh pemerintah kabupaten jember. Adapun target dan realisasi retribusi daerah di kabupaten jember dapat diketahui pada tabel berikut ini:

Tabel 4.5 Target Dan Realisasi Retribusi Daerah Kabupaten Jember Tahun 2010-2015

\begin{tabular}{|l|c|c|c|c|}
\hline & & & \multicolumn{2}{|c|}{ Selisih } \\
\cline { 4 - 5 } & & & $(\mathrm{Rp})$ & $(\%)$ \\
\hline 2010 & $100.081 .059 .297,00$ & $96.564 .208 .457,00$ & $3.516 .850 .840,00$ & 96,49 \\
\hline 2011 & $20.468 .663 .200,00$ & $20.816 .368 .771,00$ & $-347.705 .571,00$ & 101,7 \\
\hline 2012 & $40.699 .994 .000,00$ & $40.417 .112 .857,00$ & $282.881 .143,00$ & 99,31 \\
\hline 2013 & $43.333 .425 .540,00$ & $44.192 .346 .021,00$ & $-858.920 .481,00$ & 101,98 \\
\hline 2014 & $68.473 .264 .456,00$ & $62.582 .757 .396,00$ & $5.890 .507 .060,00$ & 91,39 \\
\hline 2015 & $41.433 .412 .856,00$ & $34.447 .943 .109,00$ & $6.985 .469 .747,00$ & 83,14 \\
\hline
\end{tabular}

Sumber : Dinas Pendapatan Daerah Kabupaten Jember, Diolah, 2017

Berdasarkan tabel 4.5 diatas menunjukkan bahwa target dan realisasi retribusi daerah selama kurun waktu 2010 - 2015 mengalami perkembangan yang fluktuatif. Pada tahun 2010 realisasi retribusi daerah mencapai 96,56 milyar menurun sangat drastis pada tahun 2011 yaitu sebesar 20,81 milyar. Kemudian tahun 2012 naik menjadi 40,41 milyar, tahun 2013 naik lagi menjadi 44,19 milyar dan tahun 2014 naik lagi menjadi 62,58 milyar. Kemudian pada tahun 2015 realisasi retribusi daerah kembali mengalami penurunan menjadi 34,44 milyar. 


\subsection{Kontribusi Retribusi Parkir Terhadap Pendapatan Asli Daerah Kabupaten Jember}

Berdasarkan data yang diperoleh dari studi dokumentasi dapat diketahui bahwa retribusi parkir selama beberapa tahun terakhir ini belum memberikan kontribusi yang cukup besar dalam meningkatkan Pendapatan Asli Daerah Kabupaten Jember. Seiring dengan adanya peningkatan jumlah kendaraan dari tahun ke tahun, maka peningkatan jumlah penerimaan dari sektor retribusi ini juga mengalami peningkatan. Meskipun ada kecenderungan peningkatan jumlah penerimaan, namun peningkatan itu belum terlalu siginifikan dalam mendongkrak realisasi Pendapatan Asli Daerah Kabupaten Jember. Agar memberikan kontribusi yang cukup besar seharusnya manajemen pengelolaannya dilakukan sebaik mungkin untuk mendapatkan hasil yang lebih maksimal. Untuk memberikan gambaran terhadap permasalahan tersebut, data-data yang terkumpul kemudian dideskripsikan secara kualitatif. Berikut ini dijelaskan paparan hasil data yang diperoleh peneliti selama melakukan penelitian.

Terlihat bahwa realisasi penerimaan retribusi parkir dari tahun 20102015 mengalami peningkatan. Dari data yang diperoleh, dapat dihitung berdasarkan tabel berikut ini :

Tabel 4.6 Kontribusi Retribusi Parkir Terhadap Pendapatan Asli Daerah Kabupaten Jember Selama Kurun Waktu 2010-2015

\begin{tabular}{|c|c|c|c|}
\hline Tahun & $\begin{array}{c}\text { Realisasi Pendapatan } \\
\text { Asli Daerah }\end{array}$ & $\begin{array}{c}\text { Realisasi } \\
\text { Pendapatan } \\
\text { Retribusi Parkir }\end{array}$ & $\begin{array}{c}\text { Kontribusi } \\
\%\end{array}$ \\
\hline 2010 & $1.542 .834 .970 .274,43$ & 7.019 .899 .115 & 0,455 \\
\hline 2011 & $1.882 .586 .732 .606,79$ & 7.323 .626 .239 & 0,389 \\
\hline 2012 & $2.146 .090 .218 .860,72$ & 7.919 .072 .907 & 0,369 \\
\hline 2013 & $2.366 .375 .217 .230,67$ & 8.566 .278 .286 & 0,362 \\
\hline 2014 & $2.798 .612 .164 .201,69$ & 9.011 .531 .169 & 0,322 \\
\hline 2015 & $3.116 .542 .849 .533,93$ & 9.661 .282 .833 & 0,31 \\
\hline
\end{tabular}

Sumber: Dinas Pendapatan Daerah Kabupaten Jember, Diolah, 2017 
Berdasarkan tabel 4.6 diatas dapat diketahui bahwa kontribusi retribusi parkir terhadap Pendapatan Asli Daerah terus mengalami penurunan dari tahun ke tahun. Pada tahun 2015 justru yang paling rendah, yaitu hanya $0,31 \%$ dari PAD Jember. Untuk mengetahui besarnya kontribusi retribusi parkir dalam meningkatkan Pendapatan Asli Daerah Kabupaten Jember digunakan rumus cara persentase, yaitu menurut Mardalis (2007 : 79) dalam Ellistriana (2010), sebagai berikut:

Kontribusi $=$ $\mathrm{x} 100 \%=$

Dari rumus tersebut diperoleh hasil sebagai berikut: per Tahun Anggaran/TA

a. TA $2010=$ Rp. 7.019.899.115/Rp. 1.542.834.970.274,43 x $100 \%=0,455$

b. TA $2011=$ Rp. 7.323.626.239 / Rp. 1.882.586.732.606,79 x $100 \%=0,389$

c. TA $2012=$ Rp. 7.919.072.907 / Rp. 2.146.090.218.860,72 x $100 \%=0,369$

d. TA $2013=$ Rp. 8.566.278.286 / Rp. 2.366.375.217.230,67 x $100 \%=0,362$

e. TA $2014=$ Rp. 9.011.531.169/Rp. 2.798.612.164.201,69 x $100 \%=0,322$

f. TA $2015=$ Rp. 9.661.282.833/Rp. 3.116.542.849.533,93 x $100 \%=0,31$

Dari hasil perhitungan diatas, maka selanjutnya dapat dibuat tabel berikut :

Tabel 4.7 Kontribusi Retribusi Parkir Terhadap Pendapatan Asli Daerah Kabupaten Jember Tahun Anggaran 2010-2015

\begin{tabular}{|c|c|c|}
\hline No & Retribusi Parkir Tahun & $\begin{array}{c}\text { Kontribusi Terhadap } \\
\text { Pendapatan Asli Daerah (\%) }\end{array}$ \\
\hline 1 & 2010 & 0,455 \\
\hline 2 & 2011 & 0,389 \\
\hline 3 & 2012 & 0,369 \\
\hline 4 & 2013 & 0,362 \\
\hline 5 & 2014 & 0,322 \\
\hline 6 & 2015 & 0,31 \\
\hline
\end{tabular}

Sumber: Hasil Olah Data, 2017

Berdasarkan tabel diatas dapat diketahui bahwa hasil kontribusi retribusi parkir terhadap Pendapatan Asli Daerah Kabupaten Jember tidak mengalami peningkatan dari tahun ke tahun, tetapi justru mengalami penurunan. Pada tahun 2010 retribusi parkir memberikan kontribusi sebesar 0,455 \%, sedangkan pada 
tahun 2011 retribusi parkir hanya memberikan kontribusi sebesar 0,389\%. Untuk tahun 2012 retribusi parkir memberikan kontribusi sebesar 0,369 \%, kemudian pada tahun 2013 retribusi parkir hanya memberikan kontribusi sebesar 0,362 \%. Selanjutnya pada tahun 2014 memberikan kontribusi sebesar 0,322 \%. Dan pada tahun 2015 menurun lagi menjadi 0,31 \%. Hal tersebut menunjukkan bahwa kontribusi retribusi parkir terhadap Pendapatan Asli Daerah Kabupaten Jember terus menerus mengalami penurunan selama lima tahun terakhir.

Dari hasil studi yang dilakukan diperoleh gambaran bahwa faktor-faktor yang menyebabkan tidak optimalnya kontribusi penerimaan retribusi parkir di Kabupaten Jember adalah keterbatasan personil aparatur yang mengelola pendataan retribusi parkir dan masih banyaknya masyarakat Kabupaten Jember yang belum menyadari akan pentingnya membayar retribusi parkir. Dari hasil observasi yang dilakukan ditemukan masih banyak masayarakat yang tidak membayar retribusi parkir tepat pada waktunya.

Faktor lainnya adalah masih kurangnya ketegasan dari pihak pemerintah daerah khususnya dari pihak Dinas Pendapatan Daerah Kabupaten Jember dalam memberi sanksi bagi masyarakat yang tidak memenuhi perjanjian dalam hal membayar retribusi. Faktor berikutnya adalah seringkali pemungutan retribusi parkir tidak sesuai dengan tarif yang telah ditetapkan berdasarkan peraturan yang telah ditetapkan oleh Dinas Pendapatan Daerah Kabupaten Jember.

\subsection{Upaya Peningkatan Kontribusi Retribusi Parkir Terhadap Pendapatan Asli Daerah}

Retribusi parkir merupakan salah satu pendapatan potensial untuk meningkatkan pendapatan asli daerah (PAD). Upaya ini tengah dilakukan Kabupaten Jember untuk memperbesar pendapatan daerah. Dalam rangka meningkatkan pendapatan asli daerah dari sektor retribusi parkir ini, maka Pemkab Jember melalui Dinas Pendapatan Daerah Kabupaten Jember memiliki program dan mekanisme pemungutan retribusi parkir untuk memperbesar 
pemasukan daerah. Untuk itu Pemkab Jember telah bekerjasama dengan pemerintah provinsi dan kepolisian guna meningkatkan pemasukan melalui retribusi perparkiran.

Menurut Suyanto selaku Sekretaris Pendapatan Asli Daerah Kabupaten Jember bahwa: "untuk upaya peningkatan retribusi parkir kami telah jalin MoU dengan Provinsi dan kepolisian dengan proporsi pembagian Bappeda provinsi 13\%, Kepolisian 5\% dan Pemkab Jember sebesar 82\%. Hasil kerjasama antar ketiga institusi tersebut mulai nampak dari pendapatan Jember sebesar 10 miliar dari pungutan retribusi parkir. Jika tanpa kerjasama, pendapatan hanya 1 miliar bahkan bisa kurang" (https://nusantara.news/ kontribusi-retribusi-parkirterhadap-pad-jember).

Sementara itu Abdil Furqon, sebagai perwakilan lembaga bantuan hukum konsumen Jember mengungkapkan bahwa: "jika ingin menerapkan peraturan retribusi parkir, pemerintah Kabupaten Jember harus bersikap cepat tanggap terhadap kebijakan ini. Salah satu aspek yang harus diperhatikan adalah persepsi masyarakat terhadap model parkir berlangganan”. Abdil menambahkan bahwa: "untuk menjaga kepuasan masyarakat terhadap layanan parkir, pemerintah harus memunculkan standar operasional kerja (SOP) secara ideal, karena yang dipertaruhkan adalah sumber pemasukan dari masyarakat untuk peningkatan pemasukan retribusi" (https://nusantara.news/ kontribusi-retribusi-parkirterhadap-pad-jember).

Senada dengan Abdil Furqon, anggota DPRD Jember Anang Murwanto menjelaskan bahwa: "Pemerintah Kabupaten Jember wajib untuk meningkatkan kualitas pelayanan jika memiliki ekspektasi pemasukan yang tinggi dari parker". Anang mengeluhkan karena banyaknya keluhan dari masyarakat tentang layanan parkir ini, sebagaimana ia mengungkapkan bahwa "Kami sempat mendapatkan keluhan dari masyarakat terkait pelayanan parkir, masyarakat sudah membayar parkir berlangganan, akan tetapi kualitas pelayanan masih saja rendah, bahkan beberapa kali masih ditarik uang lagi oleh petugas parkir. Ke depan pemerintah 
harus melakukan uji sampling terkait kepuasan masyarakat, sehingga bisa menjaga kualitas pelayanan parkir" (https://nusantara.news/ kontribusi-retribusiparkir-terhadap-pad-jember).

Meski Pemerintah Kabupaten Jember telah mengupayakan peningkatan penerimaan dari sektor retribusi parkir dengan memberlakukan sistem parkir berlangganan sejak tahun 2008 lalu dengan tujuan lebih efektif, murah, praktis, serta lebih murah jika dibanding dengan parkir konvensional serta insidentil pada umumnya, namun hal itu tidak sebanding lurus dengan kenyataan di lapangan. Saat ini masyarakat masih kerap mengeluhkan dengan adanya pungutan liar oleh oknum tukang parkir meski tidak semata-mata dilakukan oleh tukang parkir yang bersangkutan. Menurut Direktur Lembaga Advokasi Konsumen Jember (LAKJ), Abdil Furqan, SH., retribusi Parkir Berlangganan sebagaimana tertuang dalam Peraturan Daerah (Perda) Kabupaten Jember No. 12 Tahun 2008 tentang Retribusi Parkir Kendaraan, harusnya diimbangi dengan upaya pengawasan serta bimbingan berkesinambungan terhadap SDM tukang parkir, agar tidak mudah menyalahgunakan Tugas pokok dan fungsi (Tupoksi). Menurut Abdil bahwa: “dengan adanya pungli oleh oknum tukang parkir yang terkesan liar dan dibiarkan memang kelihatannya sepele, namun perlu dipertanyakan kemana masuknya uang hasil pungutan tersebut. Karena jika dibiarkan, maka secara tidak langsung akan terkesan "memupuk" praktek korupsi di Jember" (http://www.rri.co.id/jember/ post/berita/259358/daerah/masyarakat_jember_keluhkan_pungli_parkir.html).

Seperti diketahui, sesuai Peraturan Daerah (Perda) No. 12 Tahun 2008 tentang Parkir Berlangganan, setiap tahun melalui pembayaran pajak kendaraan untuk roda dua dikenakan biaya Rp. 20.000, Rp. 40.000 untuk kendaraan roda empat, Rp. 50.000 untuk kendaraan roda enam, dan 25.000 untuk Taxi.

Upaya lain yang telah dilakukan dalam meningkatkan kontribusi penerimaan retribusi parkir adalah dibentuknya sistem aparatur yang memadai, personalia lebih ditingkatkan dari segi sumber daya manusia dan kedisiplinan para pegawai Dispenda. 


\subsection{Kendala Dalam Upaya Peningkatan Kontribusi Retribusi Parkir}

Dari hasil studi yang dilakukan diperoleh gambaran adanya beberapa kendala atau hambatan yang dialami oleh Dinas Pendapatan Kabupaten Jember dalam upaya untuk meningkatkan kontribusi penerimaan retribusi parkir, diantaranya adalah masih belum tersedianya lahan parkir secara memadai. Selain itu, Hasil penyetoran dari para pemungut retribusi parkir masih berkurang. Kendala lainnya, adanya penyelenggara parkir yang tidak mendaftarkan dirinya sebagai wajib pajak, sehingga mengakibatkan kerugian bagi pihak Dinas Pendapatan Daerah Kabupaten Jember.

Kendala lain yang tak kalah pentingnya adalah menjamurnya 'parkir liar' yang ada di berbagai tempat di Kabupaten Jember. Masalah ini mendapatkan perhatian dari sejumlah pihak, salah satunya DPRD Jember. Ini menjadi evaluasi bagi pemerintah daerah untuk memperbarui regulasi mengenai parkir yang ada di Jember. Karena regulasi terkait parkir di Jember belum mencakup dan tidak sesuai dengan kondisi di masyarakat. Menurut Anang Murwanto selaku anggota DPRD Jember bahwa "secara umum memang perlu ada perbaikan peraturan daerah tentang masalah parkir ini, sejauh ini sejumlah regulasi yang ada di Jember belum mengatur bagaimana parkir yang diselenggarakan oleh masyarakat dan pihak ketiga". Anang menambahkan bahwa untuk parkir di badan jalan diatur khusus dengan Peraturan Daerah Nomor tahun 2009 tentang retribusi jasa umum, Pajak di luar badan jalan diatur dengan pajak parkir yang tercantum dalam Peraturan Daerah Nomor 3 Tahun 2011 tentang Pajak Parkir. Namun, dalam Perda ini tidak mencantumkan secara khusus besaran pajak. Padahal, seharusnya dalam pajak parkir ini ada regulasi khusus, mulai dari perizinan, manajemen, hingga besaran nominal tarif parkir. Sejauh ini, kendati tidak diatur dalam perda tentang pajak parkir, para pengelola parkir di luar badan jalan mengacu pada nominal retribusi parkir di badan jalan dalam soal tarif, yakni Rp 2 ribu untuk mobil dan Rp 1000 untuk sepeda motor 
Anang Murwanto meminta agar satuan kerja mengajukan revisi perda tersebut. "Parkir khusus ini belum mencakup parkir harian yang diselenggarakan masyarakat, sehingga pelaksanaan parkir atau penitipan sepeda seperti di Tawangalun tidak bisa diselenggarakan seenaknya oleh masyarakat, apalagi untuk tarif yang dikenakan kepada masyarakat lebih besar dari tarif yang ada di Perda". Dengan demikian hal ini seharusnya menjadi evaluasi bagi pemerintah daerah khususnya Dinas Pendapatan Daerah dan Dinas Perhubungan untuk memperbaiki peraturan terkait dengan masalah parkir yang diselenggarakan oleh masyarakat ini (https://www.jawapos.com/radarjember/ archive/read/2017/5/11/2617/perluperubahan-regulasi-parkiran).

Di Kabupaten Jember cukup banyak tempat khusus yang bisa diberlakukan pajak parkir khusus, seperti di terminal Tawangalun, tempat wisata, instansi vertikal, rumah sakit dan sebagainya. Anang Murwanto menambahkan bahwa "tempat-tempat ini harusnya terkena pajak parkir khusus, sehingga ada sharing untuk PAD (Pendapatan Asli Daerah) untuk Kabupaten Jember”. Sebenarnya hal ini bisa menjadi potensi pendapatan bagi Pemkab Jember. Namun, karena perangkat hukumnya, yakni Perda yang belum ada, maka potensi ini menguap begitu saja. Tentu saja hal ini menjadi kerugian bagi Pemkab Jember karena sama sekali tidak meraih PAD. Selain itu, nilai itu masuk ke kantong pribadi dan oknum saja. Bukan hanya itu, Anang mengatakan jika ini menjadi kerugian bagi masyarakat. Karena nilai tarif yang dikenakan bisa seenaknya saja. "Ini merugikan masyarakat umum," jelasnya. Selain itu, tempat penitipan kendaraan ini juga tidak sesuai dengan kondisi parkir yang dianggap memenuhi standar untuk penitipan kendaraan ini. "Paling tidak seharusnya ada izin dari stakholder dalam hal ini Dishub, mana saja yang bisa untuk lahan parkir dan tidak," tuturnya. Hal inilah yang perlu ditertibkan oleh pemerintah, sebelum keluhan masyarakat semakin banyak

Sementara itu, Isman Sutomo, Kepala Dishub Jember menuturkan pihaknya memang tidak bisa berbuat banyak untuk masalah parkir yang 
diselenggarakan masyarakat. "Kami hanya bisa memantau untuk parkir yang ada di badan jalan, misalnya untuk di depan pertokoan elizabeth di Jalan Ahmad Yani yang dikelola oleh RT. Disana pihak RT dan pertokoan mengajukan izin ke Dishub Jember". Lebih lajut Isman Sutomo mengungkapkan bahwa "Kami yang kemudian memfasilitasi dengan melihat kesesuaian dengan AMDAL (Analisis Mengenai Dampak Lingkungan) Lalin. Jika sesuai dan bisa diatur tidak masalah, sementara untuk lahan-lahan milik pribadi dan parkir khusus untuk pemasukan PAD, arahnya lebih ke Dispenda yang memiliki kewenangan”. Pihaknya juga selalu melakukan evaluasi terhadap parkir berlangganan. "Kita tahun 2017 ini meningkatkan target pendapatan. Tahun lalu target $\mathrm{Rp}$ 9,8 miliar, kami menyumbang PAD Rp 10,05 miliar,” jelasnya. Sehingga dirinya yakin jika target itu bisa tercapai Rp 10,2 miliar. Terkait dengan saran parkir khusus, Isman mengatakan nantinya akan dievaluasi karena parkir khusus seyogyanya bisa memberikan kontribusi untuk PAD Jember

\section{BAB V. PENUTUP}

\subsection{Kesimpulan}

Dari hasil penelitian yang dilakukan menunjukkan bahwa: pertama, selama lima tahun taerakhir kontribusi penerimaan Pendapatan Asli Daerah Kabupaten Jember dari sektor retribusi parkir tidak mengalami peningkatan, bahkan terjadi penurunan dari tahun ke tahun. Pada tahun 2010 retribusi parkir memberikan kontribusi sebesar 0,455\%, sedangkan pada tahun 2011 retribusi parkir hanya memberikan kontribusi sebesar 0,389\%. Untuk tahun 2012 retribusi parkir memberikan kontribusi sebesar 0,369 \%, kemudian pada tahun 2013 retribusi parkir hanya memberikan kontribusi sebesar 0,362\%. Selanjutnya pada tahun 2014 memberikan kontribusi sebesar 0,322 \%. Dan pada tahun 2015 menurun lagi menjadi 0,31\%. Kedua, upaya peningkatan retribusi parkir belum maksimal bisa dilakukan oleh Pemerintah Kabupaten Jember meskipun telah menjalin 
kerjasama dengan pihak swasta. Hal ini disebabkan karena masih adanya sejumlah kendala yang dihadapi, antara lain masih belum tersedianya lahan parkir secara memadai dan hasil penyetoran dari para pemungut retribusi parkir yang terus berkurang. Kendala lainnya, belum adanya regulasi tentang kewajiban para penyelenggara parkir untuk mendaftarkan dirinya sebagai wajib pajak. Masih banyaknya penyelenggara parkir yang tidak mendaftarkan dirinya sebagai wajib pajak mengakibatkan kerugian bagi pihak Dinas Pendapatan Daerah Kabupaten Jember. Kendala lain yang tak kalah pentingnya adalah menjamurnya 'parkir liar' yang ada di berbagai tempat di Kabupaten Jember.

\subsection{Saran}

Berkaitan dengan kesimpulan penelitian ini, maka beberapa saran yang dapat dipertimbangkan dalam meningkatkan kontribusi penerimaan daerah dari sektor retribusi parkir antara lain:

1. Pemerintah Kabupaten Jember perlu mendata kembali semua lahan parkir yang ada di Kabupaten Jember dan menyediakan lahan parkir yang memadai.

2. Perlu menertibkan para juru parkir liar yang beroperasi di berbagai jalan strategis padat kendaraan parkir.

3. Perlu ada regulasi terkait penyelenggara parkir yang tidak mendaftarr sebagai wajib pajak, agar tidak menyebabkan kerugian. 


\section{DAFTAR PUSTAKA}

Anonim, Tap MPR-RI Nomor X/MPR/1998 tentang Reformasi Pembangunan Dalam Rangka Penyelamatan dan Normalisasi Kehidupan Nasional Sebagai Haluan Negara.

Anonim, Tap MPR-RI Nomor XV/MPR/1998 Tentang Penyelenggaraan Otonomi Daerah, Pengaturan, Pembagian, dan Pemanfaatan Sumber Daya Nasional yg berkeadilan Serta Perimbangan Keuangan Pusat dan Daerah dalam Rangka NKRI.

Anonim, UU No: 22 Tahun 1999, Tahun 2000, Tentang Otonomi Daerah, Harvarindo, Jakarta

Anonim, UU No: 25 Tahun 1999, Tahun 2000, Tentang Perimbangan Keuangan Pusat dan Daerah, Harvarindo, Jakarta.

Anonim, UU No: 34 Tahun 2000 Tentang Pajak Daerah dan Restribusi.

Anonim, PP. No : 25 Tahun 2000 Tentang kewenangan Pemerintah dan Kewenangan Propinsi sebagai Daerah Otonom.

Anonim, PP. No : 66 Tahun 2001 Tentang Restribusi Daerah.

Anonim, PP. No : 65 Tahun 2001 Tentang Pajak Daerah.

Anonim, Peraturan Daerah Kabupaten Jember No : 10 Tahun 2002 Tentang Parkir Kendaraan. Sekretariat Daerah Kabupaten Jember

Ardiyanto, Suwito, 1982. Dasar-dasar Kebijakan Negara,- Erlangga-Jakarta.

Haerah, Kahar, 2017. Strategi Peningkatan Pajak Daerah dari Sektor Pajak Hotel dan Restoran di Kabupaten Jember, Jurnal Politico, September 2017 Ida, Laode, 2000. Hak Kelola Rakyat Dalam Otonomi Daerah, Jakarta.

Khoirul, Ifa, 2017. Kontribusi Pajak Daerah dan Retribusi Daerah Terhadap Pendapatan Asli Daerah di Kabupaten Jember, jurnal Ilmiah Akuntansi, Keuangan dan Pajak 
Kurniawan, Panca dan Agus Purwanto, 2006. Pajak Daerah \& Retribusi Daerah di Indonesia. Malang: Bayumedia.

Liliweri, Alo, 2002. Mengembalikan Kedaulatan Rakyat, YAPPIKA, Jakarta.

Nugroho, Heru, 2000. Menggugat Kekuasaan Negara, Media Press-Yogyakarta.

Nurhadi dan Asir, 2004. Manajemen Pengelolaan Retribusi Parkir di Kabupaten Jember, Jurnal Politico

Raharjo, M. Dawam, 1983. Esei-esei Ekonomi Politik, LP3ES-Jakarta.

Sumodiningrat, Gunawan, 2000. Responsi Pemerintah Terhadap Kesenjangan Ekonomi, Rineka Cipta, Jakarta.

Surachmad Winarto, Tahun 1990, Pengantar Metode Penelitian "Dasar dan Metode", Tarsico-Jakarta.

Dokumen Elektronik:

(https://www.jawapos.com/radarjember/archive/read/2017/5/11/2617/perluperubahan-regulasi-parkiran).

(http://www.rri.co.id/jember/post/berita/259358/daerah/masyarakat_jember_ keluhkan_pungli_parkir.html

(https://nusantara.news/ kontribusi-retribusi-parkir-terhadap-pad-jember). 